Vol.24, No.2, Desember 2018

ISSN (p): 1693-590x, ISSN (e): 2686-4711

DOI: 10.36309/goi.v24i2.97

\title{
Solar Tracking System Untuk Lampu Taman STMIK AUB Surakarta Berbasis Arduino Uno
}

\author{
Robby Rachmatullah*1, Dessyana Kardha ${ }^{2}$, Dani Triwiyanto ${ }^{3}$ \\ ${ }^{1}$ Program Studi Sistem Informasi; ${ }^{23}$ Program Studi Sistem Komputer; \\ ${ }^{123}$ STMIK AUB Surakarta, Indonesia \\ e-mail: *1'robby_r@stmik-aub.ac.id, ${ }^{2}$ dessyanakardha@stmik-aub.ac.id, ${ }^{3}$ \\ Dannythrye@gmail.com
}

\begin{abstract}
Abstrak
The transfer of electrical energy sources from non-renewable fossil fuels to alternative renewable fuels can be made by utilizing solar energy. The working system of arduino uno solar tracking system for STMIK AUB garden lights is by capturing solar energy through solar panels which are then stored inside the battery where the charging process is controlled by solar charge controller. LDR functions to receive and identify the radiated light quantities which are then forwarded into the arduino uno and processed to drive the DC motor that has become one with the solar panel. If the day begins to darken the LDR will inform the arduino uno and then it will be processed by arduino uno to turn on the DC light.
\end{abstract}

Kata kunci: Arduino uno, LDR, DC motor, solar cell,DC lamp, solar charge controller

\section{PENDAHULUAN}

Indonesia adalah salah satu negara tropis yang musim panasnya cukup lama yaitu 6 bulam dari 1 tahun dan hampir setiap hari matahari menyinari seluruh pelosok Indonesia dari pagi hari hingga sore hari. Energi matahari yang terpancar dapat diubah dan di olah menjadi energi listrik dengan memanfaatkan panel surya atau solar cell. Pembangkit listrik tenaga surya adalah salah satu inovasi ramah lingkungan yang berpotensi menggantikan listrik yang di pasok oleh Perusahaan Listrik Negara (PLN).

Bumi memiliki beberapa sumber energi yang dapat di perbaharui yang tersedia, dimana dapat digunakan dalam skala besar untuk menghasilkan listrik yang cukup besar. Antara lain adalah panas matahari, angin, air, dan lain-lain. Kombinasi dari dua atau lebih sumber energi tersebut sering dikenal dengan nama Hybrid System.

Tahun 2011, Badan Energi Internasional menyatakan bahwa "perkembangan teknologi energi surya yang terjangkau, tidak habis, dan bersih akan memberikan keuntungan jangka panjang yang besar, perkembangan ini akan meningkatkan keamanan energi negara melalui pemanfaatan sumber energi yang sudah ada, tidak habis, tidak tergantung pada impor, mengurangi polusi, mengurangi biaya mitigasi perubahan iklim, dan menjaga harga bahan bakar fosil tetap rendah dari sebelumnya. Keuntungan itu berlaku global. Oleh sebab itu, biaya insentif pembangunan awal selayaknya dianggap sebagai investasi untuk pembelajaran, investasi ini harus digunakan secara bijak dan dibagi bersama." (http://id.m.wikipedia.org/wiki/energi_surya, 23.06WIB, 23 April 2014 )

Panel surya atau solar cell yang akan digunakan adalah jenis monochrystal (panel surya dengan efisiensi terbaik), sebagai komponen penting dalam pembuatan pembangkit listrik tenaga surya yang mendapatkan energi listrik pada pagi hari sampai sore hari sepanjang masih ada sinar matahari, manfaat utama dari sistem pelacakan surya adalah untuk mengumpulkan energi matahari untuk periode hari terpanjang, dan dengan keselarasan yang paling akurat sebagai posisi bergeser Matahari dengan musim.

Received November 12, 2018; Revised November 28, 2018; Accepted December 10, 2018 
STMIK AUB adalah sebuah perguruan tinggi swasta yang terletak di JL. MW. Maramis No.29, Nusukan, Banjarsari, Kota Surakarta, Jawa Tengah. STMIK AUB telah menggunakan solar cell untuk penggunaan lampu taman, yang telah dibuat oleh Hanif (2014) sebagai karya tugas akhir. namun solar cell yang digunakan masih bersifat statis menyebabkan penyerapan energi mataharinya kurang optimal dan pengontrol nyala lampu masih menggunakan timer.

Berdasarkan permasalahan yang telah diuraikan maka penulis ingin membuat sebuah alat yang bisa memaksimalkan penyerapan energi matahari dengan cara menggerakkan panel surya kearah sinar matahari dan membuat sebuah lampu yang bersifat otomatis dengan menggunakan sensor untuk menyalakan dan mematikan lampu tersebut. Maka penulis memberi judul "Solar Tracking system untuk lampu taman STMIK AUB Surakarta berbasis arduino uno".

\section{METODE PENELITIAN}

\subsection{Tinjauan Umum}

Alat yang ingin dibuat oleh penulis adalah sebah alat yang mandiri dimana alat tersebut bisa beroperasi sendiri dengan memanfaatkan energi matahari yang diserap oleh panel surya sebagai pengisi energinya, baterai sebagai media penyimpan energinya, arduino uno sebagai controller penggerak motor DC dan hidup/mati lampu, dan LDR sebagai input arduino untuk mengolah perintah.

\subsection{Metodologi Penelitian}

Beberapa metode pengumpilan data yang dilakukan bertujuan untuk mendapatkan data yang sesuai dan diharapkan sehingga pembuatan alat tepat sasaran. Adapun metodologinya sebagai berikut:

a. Data Primer, merupakan data yang diperoleh secara langsung dari sumber dengan cara :

1. Metode observasi, yaitu pengumpulan data dengan pengamatan secara langsung pada obyek penelitian (Sumber: wikipedia.org/wiki/metode_observasi). penulis melakukan pengamatan pada panel surya yang terpasang di Taman STMIK AUB.

2. Metode interview, yaitu memperoleh informasi untuk bahan pengumpulan data dari narasumer tertentu (Sumber: wikipedia.org/wiki/metode_interview), penulis melakukan Tanya jawab untuk memperoleh informasi untuk bahan pengumpulan data dari narasumer tertentu, dilakukan dengan mengajukan pertanyaan secara langsung kemudian di jawab atau dijelaskan oleh narasumber tersebut,

b. Data Sekunder, merupakan data yang diperoleh secara tidak langsung, antara lain dengan cara:

1. Literature, Merupakan metode pengumpulan data dengan cara membaca buku - buku yang mendukung dan menunjang dalam pembuatan alat (Team1, 2009) penulis melakukan pengumpulan data di perpustakaan STMIK AUB untuk menambah referensi - referensi yang mendukung penyusunan laporan.

2. Akses Internet, penulis mengakses internet untuk mencari teori teori yang akan mendukung penyusunan laporan.

c. Metode Penelitian

Pelaksanaan penelitian dilakukan dalam beberapa tahap untuk mempermudah dan memperjelas arah penelitian, yaitu tahap perancangan alat, tahap perakitan alat, pengujian alat, dan pengamatan hasil (Sumber: wikipedia.org/wiki/metode_pembuatan_alat).

Perancangan dilaukan untuk menggambar rangkaian alat dengan menggunakan software khusus, kemudian dilanjutkan ke tahap perakitan alat. Setelah alat selesai dibuat maka tahap selanjutnya adalah melakukan pengujian alat dengan beberapa parameter. Pengamatan dilakukan setelah pengujian alat

2.3 Perancangan Alat

a. Diagram blok Alat Solar Tracking System 
Untuk memudahkan dalam perancangan dan pembuatan alat maka diperlukan sebuah diagram blok, sehinngga cara kerja dari alat dapat lebih mudah dipahami, adapun diagram blok dari alat dapat dilihat pada gambar 1 :

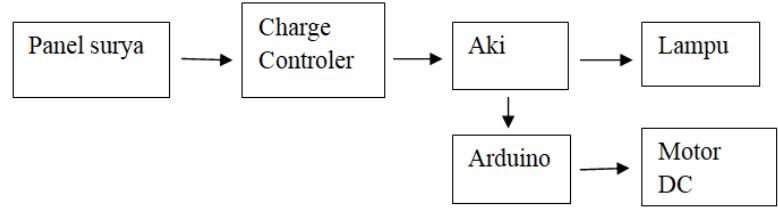

Gambar 1 Diagram blok alat solar tracking system

Berdasarkan gambar 1 maka dapat diuraikan masing-masing blok fungsional sebagai berikut:

1. Panel surya digunakan untuk mengubah energi matahari menjadi energi listrik. Energi listrik tersebut kemudian disimpan pada sebuah baterai yang disebut aki.

2. Solar Charger controller bertugas untuk mengendalikan proses pengisian arus listrik oleh panel surya, jika aki telah penuh maka Solar charger controller akan menghentikan proses pengisisan, namun jika keadaan aki kosong atau belum penuh maka Solar charge controller akan menyambung kembali proses pemgisian.

3. Baterai (aki) digunakan untuk menyimpan energi listrik yang kemudian akan digunakan untuk sumber energi arduino, charger controller, lampu, dan motor DC.

4. Arduino digunakan untuk mengontrol pengoperasian motor DC.

5. Motor DC digunakan untuk menggerakkan panel surya untuk selalu mengikuti matahari agar penyerapan energi matahari bisa optimal.

6. Lampu digunakan media penerangan dikala hari mulai gelap

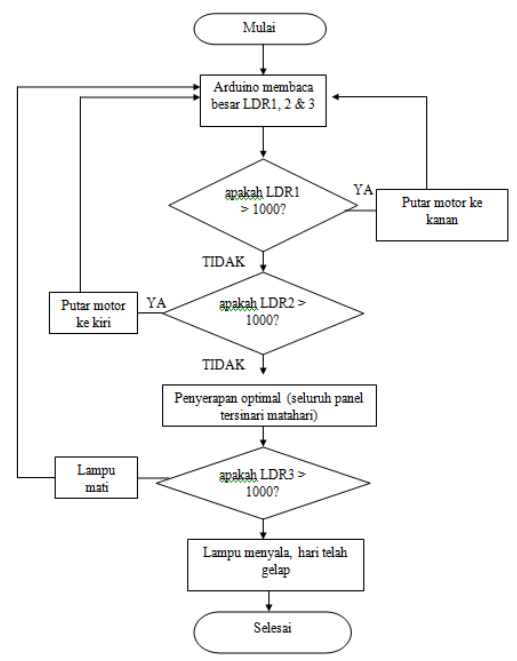

Gambar 2 Flowchart solar tracking system

Adapun keterangan dari flowchart pada gambar 2 adalah:

1. LDR menangkap sinyal analog yang kemudian dimasukkan ke dalam arduino.

2. Arduino membaca sinyal analog dari LDR.

3. Jika LDR $1>=1000 \mathrm{Cd}$ maka motor DC akan berputar searah jarum jam.

4. Jika LDR $2>=1000 \mathrm{Cd}$ maka motor DC akan berputar berlawanan jarum jam.

5. Jika nilai dari LDR 1 dan LDR $2<1000 \mathrm{Cd}$ panel mendapatkan penyerapan optimal.

6. Jika LDR $3>=300 \mathrm{Cd}$ maka lampu akan menyala dan menandakan hari telah gelap.

\section{HASIL DAN PEMBAHASAN}

\subsection{Proses Pembuatan Alat}

a. Rangkaian arduino

GO INFOTECH: JURNAL ILMIAH STMIK AUB Vol. 24, No. 2, Desember 2018 : 134 - 143 
Arduino disini digunakan sebagai pemroses dan pengontrol nyala/mati lampu, pergerakan motor DC baik dari kiri ke kanan, kanan ke kiri, maupun diam/tidak bergerak

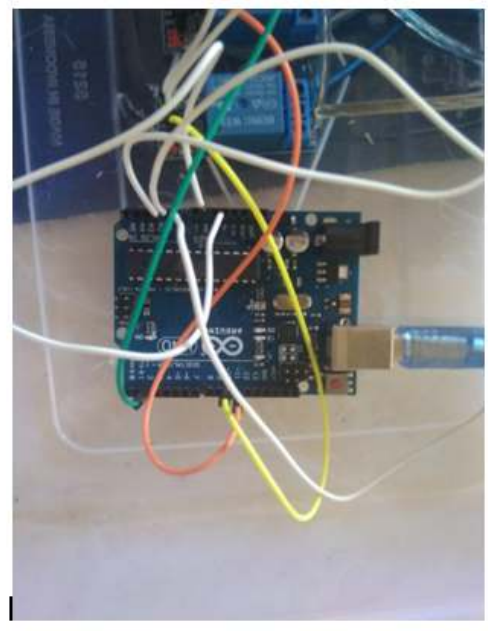

b. Rangkaian LDR

Gambar 1 Rangkaian Arduino

LDR digunakan untuk menghitung intensitas cahaya matahari yang kemudian menjadi input bagi arduino. Terdapat 3 buah LDR yang masing - masing di masukkan ke dalam pin A0, A1, dan A2 pada arduino. Untuk lebih detail bisa dilihat di tabel 1.

\begin{tabular}{|c|c|c|}
\hline \multicolumn{2}{|c|}{ Tabel 1 LDR } \\
\hline No & Pin Input & Output \\
\hline LDR 1 & A0 & Motor DC berputar searah jarum jam \\
\hline LDR 2 & A1 & Motor DC berputar berlawanan jarum jam \\
\hline LDR 3 & A2 & hidup/mati lampu taman \\
\hline
\end{tabular}

Rangkaian LDR bisa dilihat pada gambar 2

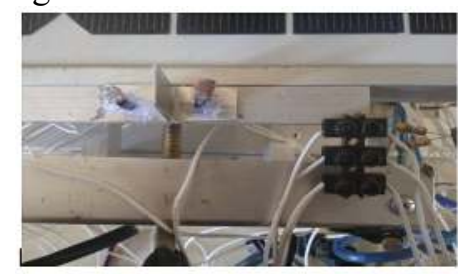

Gambar 2 Rangkaian LDR

c. Rangkaian motor DC

Motor DC digunakan untuk menggerakkan panel surya searah maupun berlawanan jarum jam dengan menghubungkan kedalam 2 buah relay yang kemudian dimasukkan ke dalam pin 7 dan 8 pada arduino sebagai output. Untuk rangkaiannya bisa dilihat dari gambar 3 .

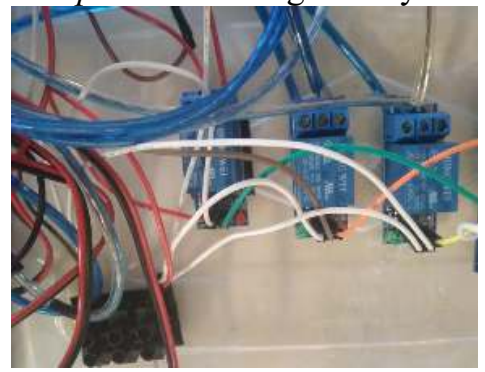

Gambar 3 relay 5v sebagai penghubung motor DC dan arduino

d. Solar charger controller

Digunakan untuk menyalurkan energi matahari yang di serap oleh panel surya kedalam baterai(aki). rangkaiannya bisa di lihat di gambar 4.

Solar Tracking System Untuk Lampu Taman STMIK AUB Surakarta Berbasis Arduino Uno 


\subsection{Cara Kerja Alat}

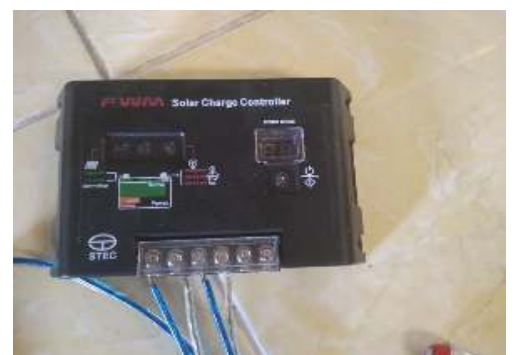

Gambar 4 rangkaian solar charger controller berikut:

Cara kerja dari alat solar charger controller berbasis arduino uno ini adalah sebagai

a. LDR akan membaca sinyal analog dari cahaya matahari yang kemudian diteruskan ke dalam arduino untuk menjadi input.

b. Arduino akan memproses input dari LDR yang kemudian digunakan untuk pengambilan keputusan, apakah akan menggerakkan motor kearah jarum jam, atau arah berlawanan jarum jam, dan untuk menghidupkan lampu.

c. Panel surya akan menangkap energi matahari yang akan di simpan ke dalam baterai.

d. Solar charger controller akan mengontrol proses pengisian baterai oleh panel surya

\subsection{Pengujian Alat}

a. Pengujian Panel surya

Tujuan dari pengujian solar cell adalah mengukur tegangan yang dikeluarkan oleh solar cell pada saat kondisi intensitas cahaya matahari yang diterima oleh solar cell berbeda - beda dan hal ini didasarkan pada kemampuan dan kapasitas solar cell yang digunakan. Berikut data sheet pada solar cell

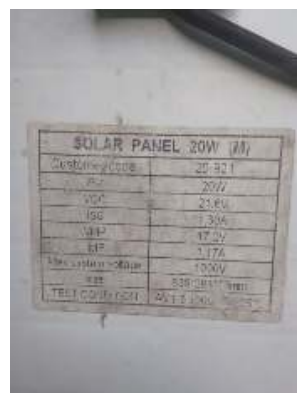

Gambar 5 data spesifikasi solar cell yang digunakan

1. Pengujian Ditempat Gelap

Pengujian ini dilakukan pada saat solar cell tidak menerima cahaya matahari sedikitpun (biasanya pada saat cuaca mendung dan malam hari). Angka yang ditunjukkan oleh voltmeter tidak menunjukan 0,00 disebabkan karena tempat gelap yang dimaksud tidak sepenuhnya gelap dan masih terdapat pengaruh cahaya di sekitar ruangan.

2. Pengujian Intensitas Minimum

a). Intensitas $1 / 4$ bagian

Pengujian ini dilakukan pada saat solar cell menerima cahaya matahari dengan intensitas minimum sebesar $1 / 4$ bagian(biasanya pada pagi dan sore hari). 


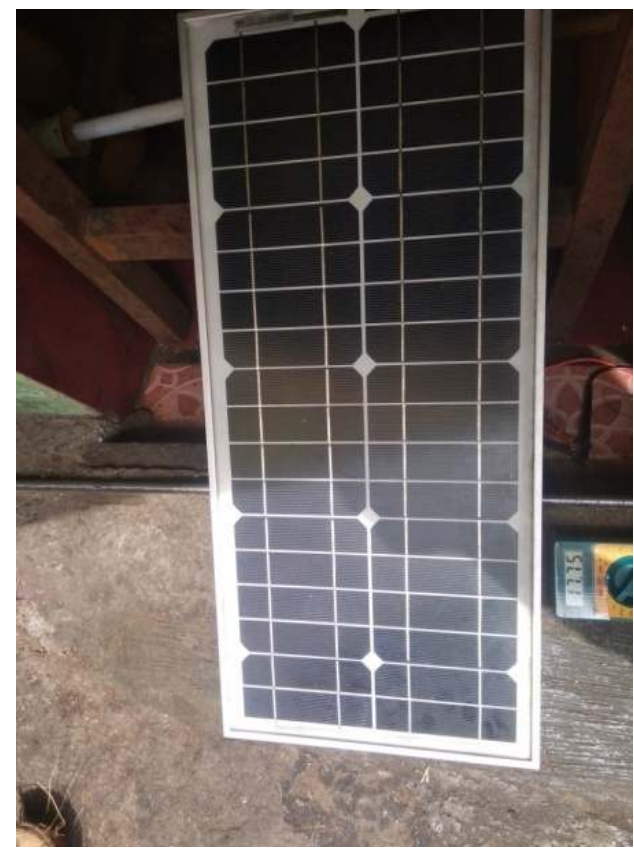

Gambar 6 pengujian Solar cell intensitas cahaya $1 / 4$ bagian Intensitas $1 / 4$ bagian menunjukkan bahwa bagian solar cell yang terkena cahaya matahari hanya $1 / 4$ bagian saja.

b). Intensitas $1 / 2$ bagian

Pengujian ini dilakukan pada saat solar cell menerima cahaya matahari dengan intensitas minimum sebesar $1 / 2$ bagian (biasa antara jam $08.00-09.00$ pagi dan jam $15.00-16.00$ sore)

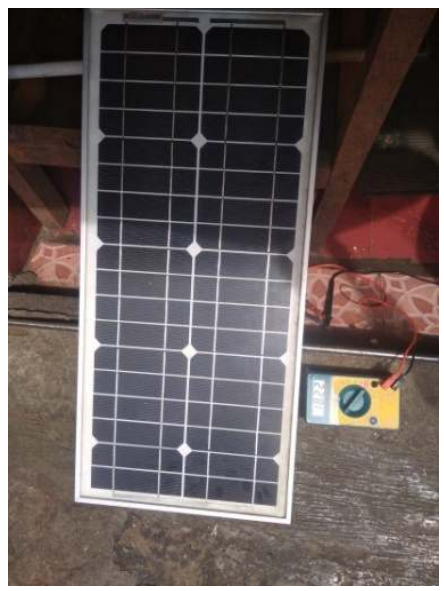

Gambar 7 pengujian Solar cell intensitas cahaya $1 \frac{1}{2}$ bagian

Intensitas $1 / 2$ bagian menunjukkan bahwa bagian solar cell yang terkena sinar matahari sebesar $1 / 2$ bagian saja.

c). Intensitas $3 / 4$ bagian

Pengujian ini dilakukan pada saat solar cell menerima cahaya matahari dengan intensitas minimum sebesar 3/4 bagian (biasa antara jam 09.00 - 10.00 dan jam 14.00 15.00). 


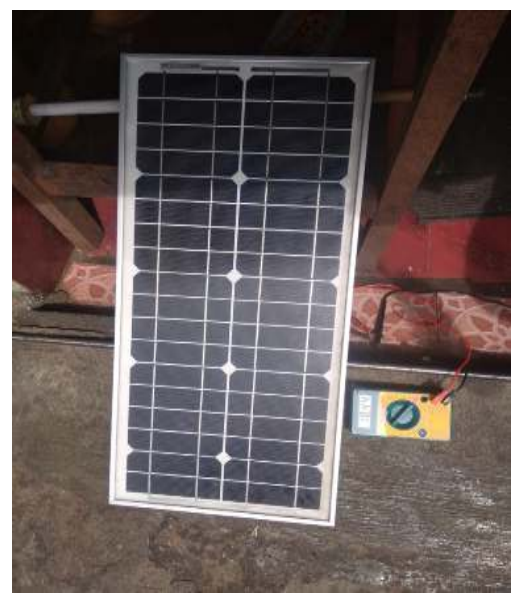

Gambar 8 pengujian Solar cell intensitas cahaya $3 / 4$ bagian

Intensitas $3 / 4$ bagian menunjukkan bahwa bagian solar cell yang terkena sinar matahari sebesar $3 / 4$ bagian saja.

3. Pengujian Intensitas Normal

Pengujian ini dilakukan pada saat solar cell menerima cahaya matahari dengan intensitas normal (biasanya pada saat menjelang siang dan menjelang sore hari).

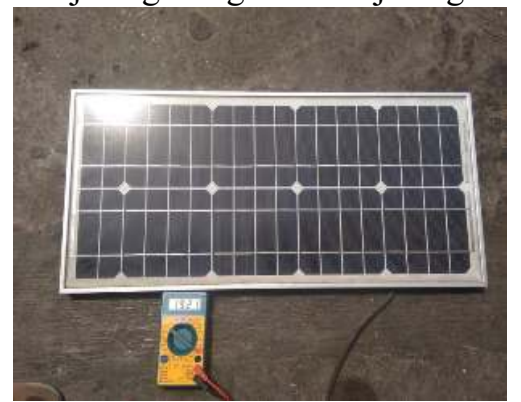

Gambar 9 pengujian Solar cell intensitas cahaya normal

4. Pengujian Intensitas Maksimal

Pengujian ini dilakukan pada saat solar cell menerima cahaya matahari dengan intensitas maksimal, intensitas matahari optimal biasanya terjadi pada siang hari antara jam 11.00 13.00

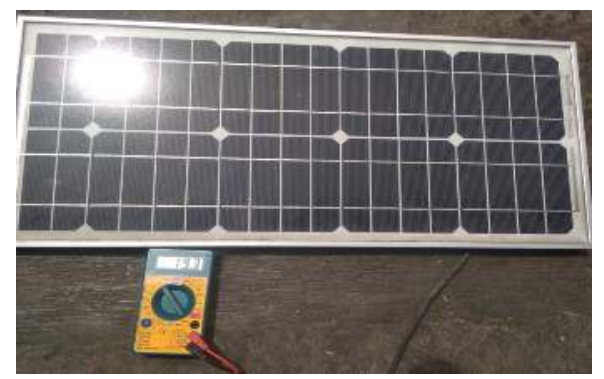

Gambar 10 pengujian Solar cell intensitas cahaya penuh

Pengamatan terhadap tegangan yang dihasilkan sesuai dengan intensitas cahaya dapat dilihat pada tabel 2 .

Tabel 2 pengamatan terhadap tegangan yang dihasilkan sesuai dengan intesitas cahaya matahari. 


\begin{tabular}{|c|c|c|}
\hline No & KONDISI & TEGANGAN-V(Volt) \\
\hline 1 & Minimum 1/4 bagian & $17,75 \mathrm{~V}$ \\
\hline 2 & Minimum $1 / 2$ bagian & $18,22 \mathrm{~V}$ \\
\hline 3 & Minimum 3/4 bagian & $18,44 \mathrm{~V}$ \\
\hline 4 & Normal & $19,21 \mathrm{~V}$ \\
\hline 5 & Maksimum & $19,30 \mathrm{~V}$ \\
\hline
\end{tabular}

Berdasarkan data sheet atau kemampuan solar cell yang digunakan, maka output yang dihasilkan berupa tegangan menunjukkan data yang mendekati dengan kapasitas yang dimiliki.

b. Pengujian Proses Pengisian Baterai

Tujuan dari pengujian ini adalah untuk mngetahui arus pengisian dari batterai pada saat kondisi intensitas cahaya matahari yang oleh diterima solar cell berbeda.

1. Pengujian Pada Arus Minimum

Merupakan kondisi arus yang dihasilkan berdasarkan tegangan yang masuk pada solar cell, merupakan arus terkecil yang dapat mengalir.

2. Proses Pengujian Pada Arus Normal

Pada pengujian ini arus normal didasarkan pada kemampuan baterai sesuai yang tertera pada data sheet baterai berkisar antara angka $0,3-0,45 \mathrm{~A}$.

3. Pengujian Pada Arus Maksimum

Dari pengujian arus diatas, dapat disimpulkan dalam bentuk tabel dan data angka pengisian arus maksimum dan arus minimum.

Tabel 2Pengisian arus

\begin{tabular}{|c|c|c|}
\hline No & KONDISI & $\begin{array}{c}\text { ARUS MASUK } \\
\text { A(Ampere) }\end{array}$ \\
\hline 1 & Minimum & $0,03 \mathrm{~A}$ \\
\hline 2 & Minimum & $0,05 \mathrm{~A}$ \\
\hline 3 & Normal & $0,45 \mathrm{~A}$ \\
\hline 4 & Maksimum & $0,50 \mathrm{~A}$ \\
\hline 5 & Maksimum & $0,51 \mathrm{~A}$ \\
\hline
\end{tabular}

Setelah adanya pengujian arus sebagai output dari aki dan pengujian tegangan berdasarkan intensitas cahaya pada solar cell sebagai output, selanjutnya pengujian terhadap suhu tempat dibandingkan dengan lama waktu pengisisan pada aki dari kondisi kosong hingga penuh. Pengujian dilakukan di daerah tertentu dengan kondisi suhu $10^{\circ} \mathrm{C}$ sampai $22^{\circ} \mathrm{C}$ di wilayah Tawangmangu, Kabupaten Karanganyar, kemudian suhu $22^{\circ} \mathrm{C}$ sampai $32^{\circ} \mathrm{C}$ di wilayah Surakarta, Jawa Tengah.

Tabel 3 Lama waktu pengisian berdasarkan suhu

\begin{tabular}{|c|c|}
\hline SUHU & WAKTU \\
\hline $15^{\circ} \mathrm{C}$ & $12 \mathrm{Jam}$ \\
\hline $15^{\circ} \mathrm{C}-22^{\circ} \mathrm{C}$ & $10 \mathrm{Jam}$ \\
\hline $22^{\circ} \mathrm{C}-32^{\circ} \mathrm{C}$ & $8 \mathrm{Jam}$ \\
\hline
\end{tabular}

Berdasarkan data pengujian alat berdasarkan arus, tegangan dan waktu pada tabel diatas maka intensitas cahaya yang semakin besar menyebabkan suhu semakin besar pula, Sehingga ketika arus pengisisan bertambah besar menyebabkan lama waktu pengisian berkurang.

\subsection{Pembahasan Alat}


Cara menggunakan alat solar charger controller berbasis Arduino uno ini sangatlah mudah yaitu cukup dengan menyambungkan rangkaian arduino ke dalam aki dan rangkaian motor DC ke dalam aki. Dengan begitu maka otomatis alat akan beroperasi dengan sendirinya.

\section{Solar charger controler}

a. Apabila lampu 1 (kiri) menyala maka berarti panel surya menyerap energi dari matahari.

b. Apabila lampu 2 (tengah) menyala hijau berarti kapasitas baterai penuh $(80 \%-100 \%)$, jika menyala kuning berarti kapasitas baterai setangah kosong (30\% - 79\%), dan jika menyala merah maka kapasitas baterai hamper habis (dibawah $30 \%$ ).

Motor DC

a Sambungkan kabel plus dan minus ke dalam relay 5 volt

b Motor otomatis berputar ke kanan dan kiri sesuai perintah yang diberikan arduino.

Baterai (aki)

1. Sambungkan kabel plus dan minus dari relay 5 volt

2. Sambungkan kabel plus dan minus dari adaptor arduino

\section{KESIMPULAN}

Berdasarkan penelitian yang telah dilakukan yaitu Solar Tracking System dengan menggunakan arduino UNO, maka dapat diambil kesimpulan sebagai berikut motor DC akan bergerak ketika ada cahaya. Ketika hari mulai gelap lampu akan menyala secara otomatis dan ketika hari mulai terang lampu akan mati secara otomatis. Pengisian baterai hanya terjadi ketika matahari menyinari bumi dan akan terputus ketika baterai telah penuh atau matahari telah terbenam. Lampu yang digunakan berjumlah 1 dan berdaya maksimal 15 Watt.

\section{SARAN}

Sebagai pengembangan lebih lanjut penelitian solar tracking system single axis berbasis arduino UNO penulis menyarankan penelitian ini baru sebatas single axis (bergerak dari timur ke barat atau sebaliknya) untuk kedepannya bisa di kembangkan menjadi double axis (bergerak dari timur ke barat maupun sebaliknya dan dari utara ke selatan maupun sebaliknya). Konversi energi dalam hal ini hanya mengubah energi matahari menjadi energi listrik, hal ini dapat dikembangkan ke dalam bentuk energi lain, misalnya dikonversikan ke energi gerak atau energi panas.

\section{DAFTAR PUSTAKA}

[1] Adi Widodo Djoko, Suryono, Tatyantoro, Tugiono. 2009. "Pemberdayaan Energi Matahari sebagai Energi Listrik Lampu Pengatur Lalu Lintas".Semarang: Universitas Negeri Semarang.

[2] Hanif Ahmad Nur. 2010. "Perancangan dan pembuatan lampu tenaga surya berbasis mikrokontroler STM8S903K3T6C" Surakarta: STMIK AUB Surakarta,

[3] Hasanudin Muhammad, 2012. "Pengaruh Perbedaan Intensitas Cahaya Terhadap Pertumbuhan dan Kadar LIPID Mikroalga Scenedesmus sp. Yang Dibudidayakan pada Limbah Cair Tapioka" Malang : Universitas Islam Negeri Maulana Malik Ibrahim Malang

[4] Hin, K. 2007. "Pemrograman Mikrokontroler PIC I6F84A". Yogyakarta: Andi Yoyakarta

[5] Kusuma, rizkya. 2010. kebutuhan akan energi listrik diambil dari”. https://www.slideshare.net/rizkyakusuma5/kebutuhan-energi-listrik-33941739

[6] Rhazio. 2007. "Penuntun ke Teknik Listrik Sinar Surya". Institute Sains dan Teknologi AL-Kamal-Jakarta Solarex Corp. PT.Dwieti Utama, Jakarta.

GO INFOTECH: JURNAL ILMIAH STMIK AUB Vol. 24, No. 2, Desember 2018 : $134-143$ 
[7] Sidopekso Satwiko, Astra I Made. 2011. "Study Rancang Bangun Solar Charger Controller dengan Indikator Arus dan Tegangan". Jakarta: Fisika FMIPA Universitas Negeri Jakarta

[8] Shen, Liang Chi dan Kong, Jin Au. 1996. “Aplikasi Elektromaknetik”. Penerbit: PT.Erlangga,Jakarta.

[9] Spektra, Jurnal Fisika dan Aplikasinya, Vol. XI No.1 Mei 2011

[10] Team1 The Dream. 2009, "Steam Engine Emulator"

[11] www.royalpv.com, 20.30 WIB, 10/06/2018

[12] www.penguintutor.com, 20.30 WIB, 10/06/2018

[13] www.idschool.net, 20.30 WIB, 10/06/2018

[14] www.arduino.cc, $21.30 \mathrm{WIB}, 08 / 06 / 2018$

[15] wikipedia.org/wiki/Arduino, 23.30 WIB, 20/06/2018

[16] wikipedia.org/wiki/panel_surya, 23.30 WIB, 20/06/2018

[17] Yusuf, fardana. 2009. Jurnal Fisika dan Aplikasinya. Vol. XI No.1 Mei 201. https://id.scribd.com/doc/184836513/listrik-merupakan-salah-satu-kebutuhanmasyarakat-yang-sangat-penting

[18] Zonaelektro. 2010. "Referensi belajar Elektronika Online". http://zonaelektro.net/motorservo/ 